\title{
Inhabiting a lettered world: exploring the fringes of Roman writing habits
}

Article

Accepted Version

Kruschwitz, P. (2016) Inhabiting a lettered world: exploring the fringes of Roman writing habits. Bulletin of the Institute of Classical Studies, 59 (1). pp. 26-41. ISSN 2041-5370 doi: https://doi.org/10.1111/j.2041-5370.2016.12016.x Available at https://centaur.reading.ac.uk/52187/

It is advisable to refer to the publisher's version if you intend to cite from the work. See Guidance on citing.

To link to this article DOI: http://dx.doi.org/10.1111/j.2041-5370.2016.12016.x

Publisher: Wiley

All outputs in CentAUR are protected by Intellectual Property Rights law, including copyright law. Copyright and IPR is retained by the creators or other copyright holders. Terms and conditions for use of this material are defined in the End User Agreement.

\section{www.reading.ac.uk/centaur}

\section{CentAUR}

Central Archive at the University of Reading

Reading's research outputs online 


\section{Inhabiting a Lettered World: Exploring the Fringes of Roman Writing Habits}

\section{Introduction}

Roman epigraphy, the study of the inscriptions of the Roman world, is a wellestablished and reasonably well-defined discipline - at least as far as those inscriptions are concerned that sit at the very centre of the discipline. It could be defined as the systematic collection and study of inscribed objects of stone, metal, and other durable matters - or, in other words, of objects that happen to be inscribed, as part of a larger communicative setting of a material world, of which the text itself, however, may not have been a focal part. Moreover, it is established practice to highlight the division into specific types of inscriptions, derived from their communicative purpose and their Sitz im Leben. ${ }^{1}$ When taken together, these particular manifestations of human language appear to constitute what has aptly been called the epigraphic habit of the communities of the ancient world. ${ }^{2}$

The boundaries and the fringes of this discipline are rather less well-defined, however. Of course, definitions cannot ever be right or wrong by default. Definitions are agreed-upon conventions, and as such they can only be assessed in terms of their overall usefulness and their fitness for purpose. In that respect, while fuzziness in definitions may be unsettling to some, ${ }^{3}$ the absence of strictness in the definition of

\footnotetext{
*Earlier versions of this paper were presented in November 2013 at the 'Manuscript and Epigraphy' conference, organised by the SFB 950 'Manuscript Cultures' at the University of Hamburg and at the 2013 Autumn Colloquium of the British Epigraphy Society in London. I am most grateful to my audiences for their input. I am also grateful to Emma Holding for correcting the language of this paper. All remaining mistakes and inaccuracies are entirely my own.

${ }^{1}$ Cf. e. g. J.-M. Lassère, Manuel d'épigraphie romaine, Paris ${ }^{3} 2011$, I 3-14, M. G. Schmidt, Einführung in die lateinische Epigraphik, Darmstadt ${ }^{2} 2011$, 1, and, most recently, F. Beltrán Lloris, Latin Epigraphy: the Main Types of Inscriptions, in: C. Bruun - J. Edmondson (eds.), The Oxford Handbook of Roman Epigraphy, Oxford 2015, 89-110. No fundamentally different approaches were taken by A. Buonopane, Manuale di Epigrafia Latina, Rome 2009 and A. E. Cooley, Cambridge Manual of Latin Epigraphy, Cambridge 2012. - The criterion of durability, especially when used as a sole criterion, has attracted certain methodological criticism, cf. e. g. A. Bellù, Paleografi a dell'età classica, in F. Della Corte (ed.), Introduzione allo studio della cultura classica, Milano 1974, III 295 357, esp. 295.

${ }^{2}$ For the fashionable concept of the 'epigraphic habit' cf. originally R. MacMullen, The Epigraphic Habit in the Roman Empire, AJPh 103, 1982, 233-246 as well as, e. g., J. C. Mann, Epigraphic consciousness, JRS 75, 1985, 204-206, E. A. Meyer, Explaining the epigraphic habit in the Roman Empire: the evidence of epitaphs, JRS 80, 1990, 74-96, or D. E. Trout, Inscribing identity: the Latin epigraphic habit in late antiquity, in: P. Rousseau (ed.), A Companion to Late Antiquity, Chichester Malden, MA, 2009, 170-186.

${ }^{3}$ S. Panciera, What is an inscription? Problems of Definition and Identity of an Historical Source, ZPE $183,2012,1-10$, in a piece that comes across as somewhat of a stream of consciousness rather than a rigorous investigation, made a surprisingly heavy-handed attempt at (re-)defining the understanding of what makes an inscription. One wonders about the point of this: is it to define the subject, or to define the remit of an academic role? And what is its relevance for the systematic study of ancient documents?
} 
ancient epigraphy as a discipline (and its pertaining body of knowledge) may in fact be both challenging and welcome - rather than constitute an actual deficiency.

To illustrate the somewhat haphazard and random nature of the approach: scratched and painted wall inscriptions - graffiti and dipinti - are typically considered to be a central part of epigraphical studies. The same applies to curse tablets. When it comes to documentary letters, such as the Vindolanda writing tablets, however, something appears to be just different enough in their nature and purpose, so as to cause hesitation over whether or not they ought to be included - or whether these ought somehow to be treated as borderline cases. Wax tablets pose similar problems, but commonly are subsumed under the label of epigraphy. Gems appear to be inscriptions, ancient coins, in turn, not so much - although surely we would treat them as inscriptions, without a doubt, if it were not for the fact that at some point in the ancient world these specific inscribed objects were used to facilitate trade and the buying and selling of goods. ${ }^{4}$

One cannot help but observe that this approach, and the borderline examples mentioned so far, randomly cross the lines of (i) whether or not the objects in question qualify as writing materials or not, and (ii) whether or not the objects in question carry any practical or symbolic meaning other than just being a form of stationery.

Intellectually, this is a questionable approach; institutionally, it does not make any significant difference, as some of those inscribed materials that I have just singled out - letters and coins - have sparked ancillary disciplines in their own right. Yet, what exact difference between a contract on a wax tablet and a private, non-literary letter written on, or at least preserved in, the exact same medium, would justify such a decision ultimately remains anybody's guess. Ultimately it seems futile to aim for a precise definition of epigraphy just for the sake of clear-cut decisions when it comes to the inclusion or exclusion of materials: if there are shared features between texts, then it is irrelevant as to whether their respective classification unites them or sets them apart. In turn, if there are markedly distinctive features between texts that have been classified as belonging to the same category, then this distinction is unlikely to shake the foundations of the discipline. So why bother?

The present paper will work forward from the following assumption: what initially may not appear to be a problem, when it comes to epigraphy as an academic discipline, may still have rather significant knock-on effects. These affect both issues of methodology and the general scholarly perception of the role and spread of writing (and its conceptualisation) in the ancient world. In other words, if one would like to (i) explore the epigraphic habit of the ancient world, or (ii) to understand something about the role of non-literary writing (and the discourse about it) in the ancient world, it is precisely at the fringes of the epigraphic habit that one will make particularly significant and wide-ranging discoveries.

General assessment of the ancient world, including its levels of literacy and the relevance of writing, ${ }^{5}$ is to no small extent shaped by the nature of the material

\footnotetext{
${ }^{4}$ One may wish to note, as was pointed out to me, that A. Degrassi (in ILLRP) and E. H. Warmington (in Remains of Old Latin IV) indeed included coins, a practice that has much less of a tradition in corpora of inscriptions of the imperial period.

${ }^{5}$ The traditional approach to literacy in the ancient world, originally proposed most notably by W. V. Harris, Ancient Literacy, Cambridge, MA 1989, now heavily dated, requires continued re-thinking. For a short and entirely judicious selection of relevant publications one might refer to e. g. M. Beard et al. (edd.), Literacy in the Roman World (JRA suppl. 3), Ann Arbor 1991 (specifically on Pompeii in this volume: J. L. Franklin Jr., Literacy and the parietal inscriptions of Pompeii, pp. 77-98), A. Bowman G. Woolf (edd.), Literacy and Power in the Ancient World, Cambridge 1994, W. Johnson, Toward a Sociology of Reading in Classical Antiquity, AJPh 121, 2000, 593-627, J. Watson (ed.), Speaking
} 
that is typically covered by, and arranged by, those ancillary ${ }^{6}$ disciplines that focus, at least to some extent, on carriers of verbal information - manuscripts, papyri, inscriptions, coins, letters. There were, however, further texts - attested either directly or mentioned in other sources - that fall between these categories, as they appear to be too casual, insignificant, and non-permanent to include them more prominently in treatises that focus on the aforementioned areas. Moreover, the less durable, or in fact in some cases even particularly perishable, nature of the carriers of information, resulting in low frequency of attestation, has exercised a potentially rather significant bias on our epigraphic corpora and resulted in a distorted perception of the ways in which epigraphic scholarship should be defined. ${ }^{7}$ This paper will focus on such forms of writings and their connotations - writing that (without aby desire to introduce strict classifications or made-up divisions) may broadly be subdivided into 'perishable writing' (related to the highly perishable nature of the writing material) and 'living texts' (emphasising the animate nature of the writing material at its time of use).

The implication of all this is, of course, that writing actually was (or at least: was imagined to be) rather more widespread in the real lives of ancient peoples than typically reported in relevant scholarship. To bring these ramifications to the fore is thus not so much an exercise in merely reframing the concept of instrumentum domesticum and the like, ${ }^{8}$ much rather, it is an essential exercise in creating a more accurate, multi-faceted picture of the ancient world as a fundamentally lettered world, adding an important - if at times somewhat playful - dimension to an otherwise perfectly serious field.

\section{Perishable Goods, Perishable Writing}

Volumes: orality and literacy in the Greek and Roman world (Mn. suppl. 218), Leiden et al. 2001, A. E. Cooley (ed.), Becoming Roman, Writing Latin? Literacy and Epigraphy in the Roman West (JRA suppl. 48), Portsmouth, RI 2002, and W. A. Johnson - H. N. Parker (edd.), Ancient Literacies: the Culture of Reading in Greece and Rome, Oxford - New York 2009. For a slightly different angle on the same issue, focusing on an analysis of discourse, see now P. Kruschwitz, Reading and Writing in Pompeii: an Outline of the Local Discourse, in: N. Cannata-M. Signorini (edd.), Scrivere, leggere, conservare. A colloquio con A. Petrucci (= Studj Romanzi n. s. 10) 2014, 245-280.

${ }^{6}$ The notion of an 'ancillary' discipline has caused some discontent in those who find themselves working in an area that they do not regard as support work at all, but as quintessential scholarship carried out for its own sake; cf. S. Panciera, Epigrafi, epigrafia, epigrafisti. Scritti vari editi e inediti (1956-2005) con note complementari e indici, Rome 2006, 12 ff., J. de Santiago Fernández, La epigrafía: evolución conceptual y metodológica, in Documenta \& instrumenta, 1, 2004, 203-220, or S. A. Takács, Foreword, in F. Feraudi-Gruénais (ed.), Latin on Stone, Lanham 2010, xv. This debate, however, is a ideological and political one (in terms of academic jobs and institutions), not an intellectual one, as epigraphy continues to inform the very same academic disciplines that were involved originally in precisely the same ways as before, practitioners come from the exact same backgrounds as before, often with little or no regard to the approaches from other contributing disciplines, and jobs continue to be spread out over the exact same departments as before as well.

${ }^{7}$ For earlier criticism of this issue see above, nt. 1. This must not be mistaken as a comment on overall lack of academic interest in Kleininschriften, which have seen a significant increase in scholarly attention; cf. e. g. the publications of the Instrumenta inscripta latina series (vol. I ed. M. Hainzmann Z. Visy, Pécs 1991; vol. II ed. M. Hainzmann - R. Wedenig, Klagenfurt 2008; vol. 3 ed. G. Baratta S. M. Marengo, Macerata 2012; vol. IV (Nulla dies sine littera. La escritura cotidiana en la casa romana) ed. G. Baratta, Barcelona 2012); vol. 5 ed. A. Buonopane - S. Braito, Rome 2014).

${ }^{8}$ I therefore deliberately omit discussions related to carriers of lettered information such as bricks, tiles, mirrors, etc. 
Recent decades saw a paradigmatic shift in the study of ancient inscriptions. Moving on from an era in which inscriptions were understood as texts that merely happened to be inscribed, key influential scholars have argued that inscriptions are in fact objects that serve a specific purpose, but also happen to be inscribed. This paradigmatic shift has raised awareness for the fact that the inscription is but part of a (potentially rather more important) communicative micro- and macro-context that must be understood before one can engage meaningfully with an inscription's actual wording.

While this is a valid and important observation, it fails to acknowledge a simple truth: typically, whatever the objects were that 'happen to be inscribed', in most cases these objects are still deliberately prepared to be inscribed, and they are inscribed in very specific, conventional ways. The same cannot, or not necessarily, be said, however, for the following range of inanimate objects - which arguably is the precise reason as to why this segment constitutes (what, for the purpose of the present paper, might be called) 'fringe epigraphy'.

\subsection{Devouring Texts: Inscribed Foodstuffs}

The ruins of Herculaneum, obliterated by the eruption of Mt Vesuvius in A. D. 79, yielded a great number of remarkable finds. Among the more unusual ones were numerous carbonised loaves of bread, several of which bear the impression of a stamp that reads as follows:

$$
\begin{aligned}
& \text { Celeris Q(uinti) Grani|Veri ser(ui). } \\
& \text { Of Celer, the slave of Quintus Granius Verus. }
\end{aligned}
$$

An actual stamp, or signaculum, if with a spelling variation of the name Grani has also been discovered - in Rome, interestingly enough, rather than in Pompeii. ${ }^{9}$ Latin epigraphical scholarship, in response to this discovery, has focused on the logistics of bread production of Herculaneum, and on the persons mentioned in the inscription. ${ }^{10}$ For the purpose of the present paper, however, the truly remarkable aspect of this text is, of course, something else - an aspect that lies in the very serendipitous way in which this text has survived: for, if the actual loaves had not survived, would we ever have assumed that the signaculum had been used to impress this very information into bread? Would we have assumed that the surviving signaculum was in fact used in order to produce inscriptions that quite literally were to be consumed and digested?

Subsuming the inscribed bread loaves of Herculaneum under the rubric of 'inscriptions and the economy' is only one way of looking at this matter. A different approach would be to ask: what do we know about inscribed foodstuffs in the ancient world - how do inscriptions and foodstuffs go together? ${ }^{11}$ Stamping is not the only

\footnotetext{
${ }^{9} A E$ 1994.206.

${ }^{10}$ Cooley (above, nt. 1) 103 mentions this text - but it features in a section on 'inscriptions and the economy', just before she moves on to inscribed weights and measures.

${ }^{11}$ A useful overview of some of the relevant material can be found in G. Manganaro, Tra archeologia ed epigrafia: due note, ZPE 137, 2001, 189-195. For a more recent, comprehensive treatment of related material from Spain see M. Bustamente - J. Salido - E. Gijón, La panificación en la Hispania romana, in: M. Bustamente - D. Bernal (edd.), Artifices idoneos: Artesanos, talleres y manufacturas en Hispania, Mérida 2014, 319-353.
} 
way in which bread was inscribed. There is sufficient evidence for moulds that impressed their shape (with or without lettering) onto dough ${ }^{12}$ - bread, cake, and the like. A particularly interesting example of such a mould has been retrieved near Split in Croatia, where, framed by a pair of gladiators and palm leaves, one gets to read in (slightly imperfect) mirrored writing: ${ }^{13}$

Miscenius | Ampliatus |facit | Salonas (!).

Miscenius Ampliatus produced this in Salonae.

(CIL III 8831)

Baked goods, of course, share a number of characteristics with clay when it comes to their 'inscribability': they accommodate stamps and traces produced with pointy objects ante cocturam, and they harden through the process of baking - after which only scratching the surface with a sharp, pointy object will remain an option. In some cases, it is in fact almost impossible to tell which precise use a certain mould had was it for objects made of dough, or was it used for clay objects instead? An excellent example of that is an inscription that has commonly been explained as a mould for cakes to celebrate the new year: ${ }^{14}$

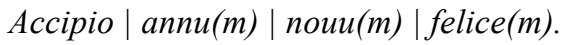

I receive a happy new year.

(CIL III 6287)

The problem is, however, that the mould itself shows two rather peculiar protrusions, which thus far have remained overlooked, ${ }^{15}$ making it entirely possible that this mould was indeed used for a different material (e. g. to produce clay or even metal tablets that were meant to be put on display in some kind of holder).

Returning to the idea of inscribed foodstuffs, however, it is conceivable either to add writing made of different material before consumption, as part of decoration and preparation, or simply to mould them into specific shapes that resemble, or at least contain, elements of writing. Based on the observation that 'alphabetic cakes' were (and continue to be) in use throughout the world, Henri Gaidoz has argued that

\footnotetext{
${ }^{12}$ For a comment on the actual process cf. $A E 2005.1108$ (from Eisenberg, Germania Superior), where an instructive inscription has been added to a stamp that was used to shape altar bread or hosts in the shape of a cross, with a chi-rho sign in the middle. The inscription in question is on the obverse, and it reads ad pane $(m)$ pingere utere felix ('press onto the bread, use with good fortune').

${ }^{13}$ Further on this item see F. Bulić, Inscriptiones quae in C. R. Museo Arch. Salonitano Spalati asservantur, Split 1886, 83 n. 826 and, more recently, M. G. Schmidt, Reflections of Roman Life and Living, Berlin - New York 2004 [available at http://cil.bbaw.de/pdf/reflections.pdf], 20 no. 7 (with photo of a squeeze).

${ }^{14}$ See e. g. A. Alföldi, Die alexandrinischen Götter und die Vota Publica am Jahresbeginn, JbAC 8-9, 1965-1966, 53-87, esp. 67 and B. Perc, Beiträge zur Verbreitung ägyptischer Kulte auf dem Balkan und in den Donauländern zur Römerzeit: mit besonderer Berücksichtigung des Quellenmaterials aus dem Gebiet des heutigen Staates Jugoslawien, Munich 1968, 53.

15 An image is available at http://www.mihaigramatopol.ro/images/stories/artrom/gray/063.jpg (accessed February 2015).
} 
the following passage in Horace may in fact allude to a similar practice in the ancient world: ${ }^{16}$

(...) ut pueris olim dant crustula blandi
doctores elementa uelint ut discere prima

Just as teachers, with the intention to gain an affection, on occasion give the boys cake, so that they develop the desire to learn their first letters of the alphabet.

(Hor. sat. 1.1.25-26)

It is safe to assume that Gaidoz got carried away with an idea and thus proposed to overinterpret this passage. Yet, as Gaidoz rightly points out, the deliberate shaping of baked goods to resemble objects was not at all unknown - most famously, Scipio is reported to have had prepared a cake in the shape of the city of Carthage, ordering it to be 'plundered'. ${ }^{17}$ So whether or not Horace gives early evidence for alphabetic cakes or not - there is little reason to rule out their existence for the ancient world categorically, and it is perfectly thinkable that they played a role in ancient primary education, as Henri Marou, too, appears to acknowledge. ${ }^{18}$ Or, to return to the earlier imagery regarding the 'consumption of texts', this may have been a way for teachers to ensure that their students would, quite literally, swallow the content of their lessons.

Other foodstuffs lend themselves rather less easily to the purpose of inscribing, due to their very consistency. That does not mean that it is altogether impossible to attach texts to them, however. Recent excavations in Germany, for example, have produced price tags, made of lead (presumably so that they could be amended more easily, due to the malleable nature of this particular metal), for a number of different foodstuffs, including asparagus, sparrows, and, possibly, ravens. ${ }^{19}$ Based on this evidence, it would seem perfectly plausible to assume that other means of indicating the price (origin, quality, quantity) existed as well - e. g. on wooden boards, on slate, or whatever other material one can think of that lends itself for display and cheap re-use.

Inscribing foodstuffs in the ancient world is, of course, not exclusively a practice that is part of the experienceable, real world. It is also an act that comes with certain, quasi-magical connotations. This is, as has been seen by literary scholars (but never by epigraphists, it would appear), particularly true for one foodstuff, namely apples. ${ }^{20}$ Whether it is the apple of discord, allegedly inscribed $\tau \tilde{\eta} \kappa \alpha \lambda \lambda i$ in fairest', ultimately sparking off the Trojan war, or the apple in the story of Acontius and Cydippe, where the inscription on the apple, when read out aloud, becomes

\footnotetext{
${ }^{16}$ H. Gaidoz, Les gateaux alphabétiques, in: Mélanges Renier; recueil de travaux, Paris 1887, 1-8, esp. 6.

${ }^{17}$ Plut. Apophthegmata of Scipio (Moralia) 11.

${ }^{18}$ H. I. Marou, A History of Education in Antiquity, Madison, Wisc. 1956, 151. 272. 432 nt. 15.

${ }^{19}$ Cf. $A E$ 2004, 946-949. - For a comprehensive discussion see L. Schwinden in M. Reuter - M. Scholz (eds.), Geritzt und entziffert: Schriftzeugnisse der römischen Informationsgesellschaft, Stuttgart, 2004. Cf. also L. Schwinden, Römerzeitliche Bleietiketten aus Trier, Zum Handel mit Pfeffer, Arznei und Kork, Trierer Zeitschrift 48, 1985, 121-137.

${ }^{20}$ A extensive discussion of this issue can be found in P. A. Rosenmeyer, Ancient Epistolary Fictions: The Letter in Greek Literature, Cambridge 2001, 98-130 (with further references). Cf. also A. R. Littlewood, The Symbolism of the Apple in Greek and Roman Literature, HSCPh 72, 1968, 147-181, E. Zaffagno, Il giuramento scritto sulla mela, MSCN 1, 1976, 109-119, and M. K. Brazda, Zur Bedeutung des Apfels in der Antiken Kultur, Bonn 1977.
} 
tantamount to an oath - a story that finds a parallel in the story of Hermochares and Ctesylla: apples represent an erotic sphere, and inscriptions on them, in their literary imaginations anyway, play an important role in that. ${ }^{21}$

Are we to assume that these carvings were simply literary imaginations, or would it not be more reasonable to assume that carving into appropriate foodstuffs was indeed a way of communication in the ancient world that is commonly neglected in academic discourse - something that could be added to a class of inscriptions that also comprises graffiti and carvings on trees?

\subsection{Elementary Texts: The Use of Toy Letters}

Whereas the existence of 'alphabetic cakes' cannot be established with any certainty for the ancient world, the existence of inedible toy letters - to support the linguistic education of the young - appears to be unambiguous. Quintilian reports the use of ivory letter-shapes as an educational tool in the first book of the Institutio Oratoria:

Non excludo autem (id quod est notum) irritandae ad discendum infantiae gratia eburneas etiam litterarum formas in lusum offere, uel si quid aliud quo magis illa aetas gaudeat inueniri potest quod tractare intueri nominare iucundum est.

I do not rule out, however, the well-known practice, for the purpose of stimulating little children to learn, the practice of offering ivory letter-shapes to play, or whatever else may be found so that this age derives the pleasure to enjoy their tracing, beholding, and naming.

(Quint. inst. 1.1.26)

A similar story, specifically with a view on the education of girls, is reported in St Jerome, who also attests to the use of boxwood (in addition to ivory) for the very same purpose. ${ }^{22}$ In this case, the writing itself does not only interact with the object, but defines it, down to the level of its very shape. This constitutes, quite literally, an elementary way of composing and deconstructing non-literary, material texts ${ }^{23}$.

\subsection{Granular Texts: Writing in the Sand}

Equally perishable as texts on foodstuffs, if for very different reasons, are texts produced in sand. The elementary force of nature is bound to let those texts vanish sooner rather than later. Unsurprisingly, no actual inscription in sand appears to have survived from ancient times. Ancient sources, however, report a number of cases in which writing in sand occurred, and they give little reason to doubt as to whether this was in fact a rather common scenario (as well as a way of jotting down information entirely free of charge). ${ }^{24}$

\footnotetext{
${ }^{21}$ Further thoughts on this as part of the epigraphic habit (rather than a mere issue of literary imagination) in P. Kruschwitz, Writing on Trees: Restoring a Lost Facet of the Graeco-Roman Epigraphic Habit, ZPE 173, 2010, 45-62, esp. 46 with nt. 7.

${ }^{22}$ Hier. epist. 107.4.2.

${ }^{23}$ Further on this see e. g. M. W. Küster, Die Tradition des alphabetischen Sortierens von der Keilschrift bis zur EDV, Tübingen 2006, 232-233.

${ }^{24}$ A particularly difficult issue is the common belief that prostitutes (male and female?) wore shoes which imprinted erotic suggestions or simple messages like 'follow me' onto the ground as they walked along: cf. e. g. D. Montserrat, Sex and Society in Graeco-Roman Egypt, London - New York
} 
As a matter of fact, this particular practice of writing is often mentioned in conjunction with learned, scientific, and philosophical discussions, where tracing in the sand helped to illustrate matters that are otherwise difficult to comprehend. Perhaps the most famous version of this is Archimedes, who, even when the Roman soldiers conquered Syracuse, was most concerned about his 'circles' - and the patchy and problematic evidence may well suggest that he was looking at drawings in the sand. There is no vulgate of this anecdote, however, so matters remain somewhat inconclusive. $^{25}$

A similarly problematic episode, combined with an interesting attitude can be seen in Cicero's De re publica, where Cicero reports a saying that he prefers to ascribe to Plato: ${ }^{26}$

quem ex alto ignotas ad terras tempestas et in desertum litus detulisset, timentibus ceteris propter ignorationem locorum animaduertisse dicunt in arena geometricas formas quasdam esse descriptas; quas ut uidisset, exclamauisse, ut bono essent animo; uidere enim se hominum uestigia; quae uidelicet ille non ex agri consitura, quam cernebat, sed ex doctrinae indiciis interpretabatur.

For when a storm at sea had driven him to an unknown land and stranded him on a deserted shore, and his companions were frightened on account of their ignorance of the country, he, according to the story, noticed certain geometrical figures traced in the sand, and immediately cried out, 'Be of good courage; I see the tracks of men.' He drew his inference, evidently, not from the cultivation of the soil, which he also observed, but from the indications of learning.

(Cic. rep. 1.29.2, transl. C. W. Keyes)

This seemingly inconspicuous story has drawn attention to a significant range of issues - the concept of Bildung in particular ${ }^{27}$-, just not the most obvious one, namely as to whether the Romans, too, used to draw letters in the sand.

The passage may, at first glance, not look very spectacular. It touches upon at least two important aspects, however, that should be considered further (despite the complete absence of direct evidence for this practice). The first one is the use of writing on the (sandy) ground for educational purposes. The second one is the information that geometrical figures were written in this material - moving on from an unhelpful, narrow definition of 'text' as word/writing-code-based, towards a

1996, 129 and T. J. Bauer, Philosophen, Mönche und Hetären. Die Apophthegmata Patrum im Schnittfeld von Theologie und Klassischer Philologie, in: U. Egelhaaf-Gaiser - D. Pausch - M. Rühl (edd.), Kultur der Antike. Transdisziplinäres Arbeiten in den Altertumswissenschaften, Frankfurt a. M. 2011, 112-128, 121 with nt. 30, to mention but two examples. Although it seems perfectly possible that this was in fact what happened on occasion, the evidence for this view is sketchy at best. Apart from a rather ambiguous passage (with regard to what has actually been placed underneath the sole) in Clement of Alexandria (Paedagogus 2.11 PG VIII 537-538), there appear to be only vessels surviving that take the shape of a shoe and contain such message (AKO $\Lambda \mathrm{OY} \Theta \mathrm{I})$, cf. J. J. Winkler, The Constraints of Desire. The Anthropology of Sex and Gender in Ancient Greece, New York - London 1990, 109 and nt. 147.

${ }^{25}$ The proverbial noli turbare circulos meos ('don't disturb my circles') is derived from Val. Max. 8.7.ext.7, where Archimedes, who just before his death busily oculis in terra defixis formas describit ('traced forms in the ground, keeping his eyes firmly on them') asks the enemy soldier 'noli ... 'obsecro, istum disturbare' ('do not disturb it, I beseech you').

${ }^{26}$ Vitr. 6.1 reports the same anecdote for the Socratic philosopher Aristippus.

27 The episode is famously alluded to in Immanuel Kant's Kritik der Urteilskraft ('Critique of Judgement), § 64. - More recently and more humbly, it has been discussed in the wider context of ancient concepts of education e. g. by P. Riemer, Der Bildungsgedanke in der griechisch-römischen Antike; in: K. M. Girardet (ed.), Bildung. Ziele - Wege - Probleme (Annales Universitatis Saraviensis 22), St. Ingbert 2004, 47-62, esp. 52-53. 
concept that includes images, studies interaction between written code and image, and finally considers layout more widely. ${ }^{28}$

Incidentally, the idea that tracing symbols (and letters) in the sand is an indication of intelligence is not necessarily restricted to human interactions. ${ }^{29}$ The Elder Pliny, in the eighth book of his encyclopedic work Historia Naturalis, reports the following occurrence in a section that otherwise discusses the general intelligence of elephants: ${ }^{30}$

Mucianus III consul auctor est aliquem ex iis et litterarum ductus Graecarum $d<i>$ dicisse solitumque perscribere eius linguae uerbis: 'Ipse ego haec scripsi et spolia Celtica dicaui,' (...).

Mucianus who was three times consul reports that one of them (sc. of the elephants) had learnt the traces of the Greek letters, and used to write in words of that language: 'I myself wrote this and dedicated the Celts' spoils;' (...).

(Plin. nat. 8.6)

This dedicatory inscription for spoils, was, it would appear (if one can take this story at face value), executed by the elephant - presumably with some sort of stick as writing implement, and it would not seem altogether mistaken to assume that this happened in the sand. ${ }^{31}$ The text, of course, does not give any clear indication.

A similar story is transmitted in Aelian's work On Animals; here, the elephant was apparently made to write on wax tablets - if with some supportive guidance: ${ }^{32}$

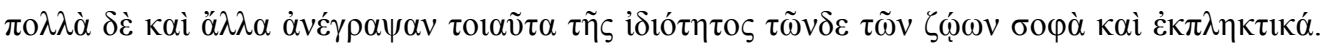

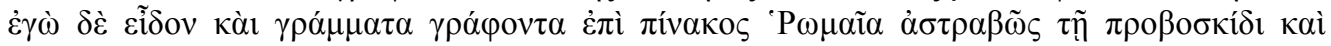

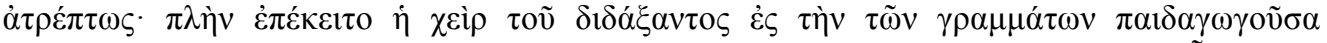

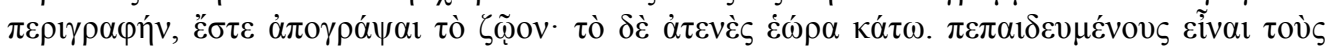

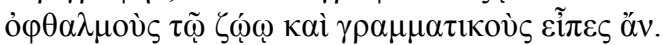

Many similar stories have been recorded showing the astounding ingenuity of these animals. And I myself have seen one actually with his trunk writing Roman letters on a tablet in a straight line without any deviation. The only thing was that the instructor's hand was laid upon it, directing it to the shape of the letters until the animal had finished writing; and it looked intently down. You would have said that the animal's eye had been taught and knew the letters.

(Aelian, De Natura Animalium 2.11, transl. A. F. Scholfield)

\footnotetext{
${ }^{28}$ The latter is all the more important as the use of image-related information in ancient documentary and technical texts is still not sufficiently understood and studied in Classical Scholarship.

${ }^{29}$ Cf. e. g. L. Kalof, Looking at Animals in Human History, London 2007, 35.

${ }^{30}$ On the background and context of Mucianus' report cf. e. g. G. Williamson, Mucianus and a touch of the miraculous: pilgrimage and tourism in Roman Asia Minor, in: J. Elsner - I. Rutherford (eds.), Pilgrimage in Graeco-Roman and Early Christian Antiquity:Seeing the Gods, Oxford - New York 2005, 219-52, esp. 236-237.

31 T. Fögen, Animal Communication, in: G. L. Campbell (ed.), Oxford Handbook of Animals in Classical Thought and Life, Oxford 2014, 216-232, 223, perhaps somewhat idiosyncratically, criticises Pliny for his unwillingness to question as to how an elephant might have been able to perform this act anatomically.

${ }^{32}$ S. D. Smith, Man and Animal in Severan Rome: The Literary Imagination of Claudius Aelianus, Cambridge 2014, 83-86 discusses both Aelian and Pliny and observes the reversal of code between the Roman author (where the elephant writes in Greek letters) and the Greek author (where the elephants writes in Roman letters). He then comes up with a rather far-fetched interpretation of cultural appropriation and critique, which well exceeds the relevance of these narratives in their respective authors, however.
} 


\subsection{Textile Texts}

Not altogether unrelated to the question of what constitutes a text is the next category, a result of yet another rather obvious, and also rather perishable, writing material textiles. Evidence for this particular manifestation of writing - historically more commonly associated with post-antique cultures (especially Byzantium and the Coptic and Islamic communities around the Mediterranean) - is scarce, at least when it comes to Latin; the situation would change dramatically, of course, if we were to extend our considerations to Roman Egypt.

Recently, Cäcilia Fluck and Gisela Helmecke edited a useful volume on 'Textile Messages: Inscribed Fabrics from Roman to Abbasid Egypt', ${ }^{33}$ and one may expect an increased amount of scholarly attention to this matter soon. Similarly, a recent article by Giulia Baratta explores inscriptions on leather. ${ }^{34}$ At this stage, however, significant groundwork still needs to be done, and it is important to see this practice not just as a phenomenon that can be detected at the margins of the ancient world. If one were to extend one's definition of writing to include the use of signals and code more generally, one could even see the use of black and white sails, as famously reported in the Theseus myth, as a form of communication by cloth. More strictly to the point, however, one may want to consider and re-evaluate the evidence for inscribed textiles that exists even for the communities and eras that lie at the centre of the Classical world.

One such piece of evidence is a brief comment in Juvenal's eighth satire. One of his insults against Lateranus, a nobleman of dubious morals according to Juvenal, reads as follows:

indulge ueniam pueris: Lateranus ad illos thermarum calices inscriptaque lintea uadit maturus bello Armeniae Syriaeque tuendis amnibus et Rheno atque Histro; (...).

Be lenient on the boys: Lateranus headed for those bathhouse wine cups and the inscribed linen awnings when he was old enough to be on guard duty in war at the Armenian and Syrian rivers, the Danube and the Rhine; (...).

(Iuv. 8.166-170)

The exact meaning of inscripta lintea, inscribed linen curtains, is unclear - it may refer to awnings, it may refer to curtains that separated the rooms available for prostitution from other areas - and depending on this, one would have to imagine different content of those inscriptions, and, potentially, also different forms of execution - from embroidering to the attachment of some sort of label. The possibility that this inscription is somehow related to prostitution could be supported by a

\footnotetext{
${ }^{33}$ C. Fluck - G. Helmecke (eds.), Textile Messages: Inscribed Fabrics from Roman to Abbasid Egypt, Leiden 2006.

${ }^{34}$ G. Baratta, Pelles scriptae: Inschriften auf Leder und Lederwaren, in: M. Hainzmann - R. Wedenig (edd.) Instrumenta Inscripta Latina II, Klagenfurt 2008, 1-23.
} 
number of passages, ${ }^{35}$ including one from Seneca's Controversiae 1.2, where the case of a former prostitute is debated: ${ }^{36}$

stetisti cum meretricibus, stetisti sic ornata ut populo placere posses, ea ueste quam leno dederat; nomen tuum pependit in fronte; (...).

You stood with the prostitutes, you stood there, beautified to please the people, with that very outfit that the pimp had given you. Your name hung at the door; (...).

(Sen. contr. 1.2.7)

Was it this particular sort of label, on occasion attached to a curtain (rather than a wooden door), that Juvenal was referring to in his satire ${ }^{37}$ Such signs, if they in fact existed, may well have included information on the cost of the various services, too, as is also suggested by another passage of the same text. ${ }^{38}$

A form of textile that commonly is associated with the Roman world and, when produced as a replica, typically is thought of as being inscribed, is the standard of the Roman army, the uexillum. The only uexillum that seems to have survived from the ancient world, however, is uninscribed. ${ }^{39}$ There are, however, perfectly good reasons to assume the 'inscribed' (or rather: embroidered) nature of these cloths, including representations of standards in sculpture (e. g. on distance slabs), as the following example, found in Bridgeness, now kept in Edinburgh, can show (text of the inscribed uexillum, in the scene on the right, given in bold letters): ${ }^{40}$

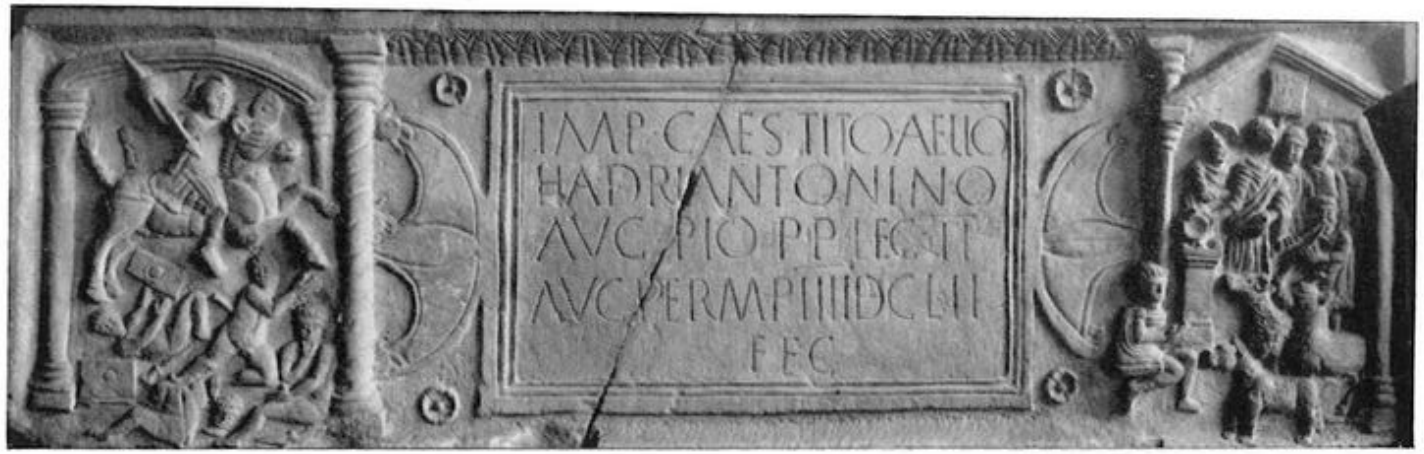

Imp(eratori) Caes(ari) Tito Aelio | Hadri(ano) Antonino | Aug(usto) Pio p(atri) p(atriae) leg(io) II | Aug(usta) per m(ilia) p(assuum) IIIIDCLII |fec(it) || Leg(io) II Aug(usta).

\footnotetext{
${ }^{35}$ Cf. e. g. Mart. 11.46. Juv. 6.122-124.

${ }^{36}$ For a more extensive discussion of the passage and its background cf. R. Langlands, Sexual Morality in Ancient Rome, Cambridge 2006, 258-260.

${ }^{37}$ With a view on the biblical passage Rev. 17:5, especially when combined with Seneca's evidence, there has been some discussion as to whether it was part of the ancient custom to inscribe the name of a 'husband' on a headband attached to a prostitute's forehead (note the ambiguity of in fronte in the Latin of Seneca's passage). Further on this see H. Roose, The Fall of the Great Harlot and the Fate of the Aging Prostitute, in: A. Weissenrieder - F. Wendt - P. v. Gmünden (eds.), Picturing the New Testament. Studies in Ancient Visual Images, Tübingen 2005, 228-252, esp. 233-234 with nt. 29 (2).

${ }^{38}$ Sen. contr. 1.2.1.

${ }^{39}$ See M. Rostovtzeff, Vexillum and Victory, JRS 32, 1942, 92-106.

${ }^{40}$ For a substantial discussion of the implications of this pictorial element's appearance on the inscription and its significance in the context of the Roman occupation of Britain see D. J. Breeze, The Flag of Legion II Augusta on the Bridgeness Distance Slab, Proc. Soc. Antiq. Scot. 119, 1989, 133142. - Image source: http://db.edcs.eu/epigr/bilder.php?bild=\$RIB_01_02139.jpg (accessed February 2015).
} 
$(C I L$ VII $1088=R I B$ I 2139)

Similar textile texts may have been in use in other contexts as well. A funerary monument from the City of Rome commemorates one Sextus Vetulenus Lavicanus: ${ }^{41}$

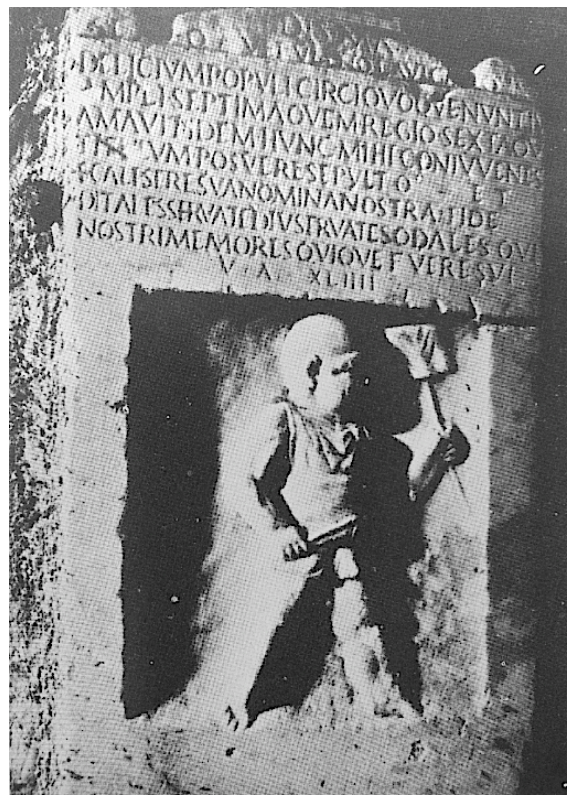

D(is) Man(ibus).

Sex[t]o Vetuleno Lauica[n]o.

delicium populi, circi quoque nuntiu(s)

ampli, septima quem regio sextaqu(e)

amauit idem. hunc mihi coniunenes

titulum posuere sepulto et

scalpsere sua nomina nostra fide.

di, tales seruate diu, seruate sodales qui

nostri memores quique fuere sui.

u(ixit) a(nnos) XLIIII.

To the Manes. For Sextus Vetulenus Lavicanus. A delight of the people, the spacious Circus's messenger, too, whom the seventh and sixth region loved equally. My fellow iuuenes erected this inscription for me in my grave and carved my name, in their typical trustworthiness. You gods, preserve such men for a long time, preserve such comrades, who have been mindful of ourselves and also of themselves. He lived for 44 years.

The text suggests that Vetulenus was a circi nuntius, and the sculpture, shows a person carrying a sign - potentially made of cloth $?^{42}$ - on a stick. ${ }^{43}$ Is this an ancient

\footnotetext{
${ }^{41}$ The text, a metrical inscription, was first published (with ample commentary) by S. Panciera, Tra epigrafia e topografia 1, ArchClass 22, 1970, 131-163, where the image, above, was published on tab. LVII.2. It since has attracted some interest with regards to its affectionate expressions (cf. e. g. C. Bruun, A Temple of Mater Matuta in the regio sexta of Rome, ZPE 112, 1996, 219-213, esp. 222) and its reference to the administrative organisation of the city of Rome (cf. e. g. M. Kleijwegt, Iuvenes and the Roman Imperial Society, AC 37, 1994, 79-102, esp. 84). Cf. also J. Lindersky, Games in Patavium, Ktema 17, 1992, 55-76, esp. 74 (republished, with ample additions, in Roman Questions II. Selected Papers [HABES 44], Stuttgart 2007, 463-491, esp. 488-489).

${ }^{42}$ An alternative, perhaps even more likely solution would be a placard made of wood: see e. g., Plut. Pomp. 45.2 and cf. M. Beard, The Roman Triumph, Cambridge, MA 2007, 12, 32, 126-127.
} 
version of a compère or a ring card girl?

\section{Living Texts}

Vetulenus, as part of his profession, helped to enact and to perform texts - and from there it is but a small step to the next stage, from the use of living beings carrying inscriptions (a practice to which one could add the attachment of price tags to slaves, for example) ${ }^{44}$ to the use of living beings as actual physical carriers of inscriptions.

\subsection{Growing Inscriptions}

To begin with the plant kingdom, the use of tree trunks to support handwritten inscriptions - the rustic counterpart to the graffiti-covered wall, so to speak - has by now been safely established for the Graeco-Roman world. ${ }^{45}$ This is true in terms of both its actual use and its idealisation and conceptualisation in literary sources.

'Tree inscriptions', however, are not the only form of inscriptions on living plants $^{46}$ mentioned in ancient sources. A remarkable narrative in this respect, preserved and developed in a number of different contexts, is the idea that, in an act of mourning, the names of Ajax and/or Hyacinthos were immortalised (in conjunction with a cry of woe) on the petals of the hyacinth flower. Vergil writes: ${ }^{47}$

dic quibus in terris inscripti nomina regum

nascantur flores, et Phyllida solus habeto.

Tell me in what lands the flowers grow that have the name of kings inscribed, and you alone shall have Phyllis.

(Verg. ecl. 3.106-107)

Ovid goes into more detail on a number of occasions, e. g. in the tenth book of the Metamorphoses:

non satis hoc Phoebo est (is enim fuit auctor honoris):

ipse suos gemitus foliis inscribit, et AI AI

flos habet inscriptum, funestaque littera ducta est.

This is not enough for Phoebus (for it was he who brought forth this honour): he himself, in his mourning, inscribed the petals, and the flower has AI AI inscribed, the letters of mourning were traced upon them.

(Ov. met. 10.214-216)

\footnotetext{
${ }^{43}$ Incidentally, this is but one of many examples for the need of significant future research to investigate image-text interactions in Roman inscriptions.

${ }^{44}$ Petr. sat. 29. Gell. 4.2.

${ }^{45}$ See Kruschwitz (above, nt. 21), with an additional comment made by S. West, Mopsus' Fair Copy (Vergil, Eclogues 5.13-5), ZPE 175, 2010, 22-24.

${ }^{46}$ As opposed to their fruit, which was already mentioned above, section 2.1 , and as opposed to papyrus, which, of course, is a plant-based form of stationery.

${ }^{47}$ On this passage see e. g. D. E. W. Wormell, The Riddles in Virgil's Third Eclogue, CQ n. s. 10, 1960, 29-32, M. J. Putnam, The Riddle of Damoetas (Virgil 'Ecl.' 3, 104-105), Mn. S. IV 18, 1965, 150-154, E. Abbe, The Plants of Virgil's Georgics, Ithaca 1965, 55-56, and M. Lipka, Language in Vergil's Eclogues, Berlin 2001, 93-94.
} 
It is safe to assume that this narrative does not provide scientific evidence for the intelligent design of the hyacinth petals. What is striking, however, is how clearly, when this myth was designed, someone had observed a feature of nature and begun to read it as a text - creating an aitiological narrative around it. ${ }^{48}$

\subsection{Animated Texts}

The 'inscription' of the petals, to express a deity's morning, leads on to a slightly different form of 'marking up' of living beings, namely that of animals and humans a unity that in the context of Graeco-Roman epigraphy cannot always easily be disentangled, as C. P. Jones in his article on tattooing has shown with great care and in exhaustive detail. ${ }^{49}$ The evidence for lettering and other forms of 'decoration' of animals and humans is significant and has been discussed by a number of scholars, including on the medical issues that arise from this peculiar form of mutilation. The main problem is that, due to lack of linguistic precision related to the word stigma, it is on occasion difficult to distinguish between branding and tattooing, and especially to tell the latter from the former.

Skipping the common practice of animal branding and focusing on human tattooing instead, one must note the widespread evidence for tattoos, textual and graphic, in the ancient world - with a tendency to relegate this to the margins of these civilisations, either in geographical terms or in terms of societal standing. ${ }^{50}$ A wellestablished practice was the penal mutilation of the forehead for runaway slaves, criminals, hostages, and prisoners of war. ${ }^{51}$

Tattoos were, however, not only a form of branding (as in 'producing outcasts'), but clearly in use for religious purposes, for use in the military, and even (very much as in present times) as decorative elements. As a matter of fact, even the very idea of 'fringe epigraphy', as presented here, can obtain a new, more literal meaning in this context, for there is the imagination of someone tattooing of secret messages onto a slave's shaven heads, so that the message, once the hair had grown back, could easily be transmitted without any danger of being easily obtained by adversaries. ${ }^{52}$

\footnotetext{
48 S. Papaioannou, Redesigning Achilles: 'Recycling' the Epic Cycle in the 'Little Iliad': (Ovid, Metamorphoses 12.1-13.622) (UaLG 89), Berlin - New York 2007, 162-163 comments on the phrase foliis inscribit, alluding to the leaves of a codex, which seems sensible. Overall, however, the imagery is clearly that of (sepulcral) epigraphy.

${ }^{49}$ C. P. Jones, Stigma. Tattooing and Branding in Graeco-Roman Antiquity, JRS 77, 1987, 139-155.

${ }^{50}$ But see A. Lohwasser, Haut als Medium im antiken Nordostafrika. Temporäre und permanente Modifikationen der Körperoberfläche, in: A. Berlejung - J. Dietrich, J. F. Quack (eds.), Menschenbilder und Körperkonzepte im Alten Israel, in Ägypten und im Alten Orient (ORA 9), Tübingen 2012, 527-559.

${ }^{51}$ Further on this M. Gustafson, Inscripta in fronte: Penal Tattooing in Late Antiquity, Class. Ant. 16, 1997, 79-105. Cf. also e. g. K. R. Bradley, Slaves and masters in the Roman Empire: A study in social control, Oxford - New York 1987, 120 (with relevant further sources). - Aristophanes (PCG III 2 fr. 71 ) is reported as referring to the Samian demos as $\pi \circ \lambda v \gamma \rho \alpha ́ \mu \mu \alpha \tau o \varsigma$ ('many-lettered'), an ambiguous epithet, which appears to refer to tattoos, though not necessarily to penal ones; cf. A. J. Podlecki, Pericles and his Circle, London - New York, 1998, 126.

${ }^{52}$ The story of Histiaeus of Miletus is told by Hdt. 5.35, Aen. Tact. 31.28-29, and Polyaen. 1.24.1. Further on this cf. e. g. F. S. Russell, Information Gathering in Classical Greece, Ann. Arbor 1999, 152. 157-158 and Rosenmeyer (above, nt. 20) 48.
} 
One of the most famous accounts of ancient tattooing, however, can be found in Petronius' satirical novel Satyricon, in the context of a narrative in which two men, Encolpius and Giton, pretended to have been subject to penal tattooing:

concitatus iracundia prosiliit Lichas, et: 'o te, inquit, feminam simplicem, tanquam uulnera ferro praeparata litteras biberint. utinam quidem hac se inscriptione frontis maculassent: haberemus nos extremum solacium. nunc mimicis artibus petiti sumus et adumbrata inscriptione derisi.'

Lichas lept forward, driven by anger, and said, 'Oh you witless woman, as if these wounds, prepared by iron, were to drink the letters. If only they had defiled themselves with that very kind of inscription on their forehead: we would find exceptional consolation. Now we have been had by the tricks of an actor and been ridiculed by an inscription that was merely outlined.

(Petr. sat. 106)

As Christopher Jones has pointed out, translations of this passages (and substantial scholarship on it) tend to be anything but faithful to the text, jumping to conclusions rather quickly, often taking it for evidence for penal branding (rather than tattooing). In particular, the text does not actually mention any specific form of iron - there is positively no need to assume that the implication of ferro praeparata refers to branding of any kind, as was occasionally implied. What is even more interesting, however, is the phrase uulnera litteras biberint. The speaker is suggesting, quite literally, that the wounds 'drank' (i. e. 'absorbed') the letters - which, incidentally, is the strongest evidence for the claim of tattooing rather than branding. The image is a remarkable one - allowing the skin to drink the very writing, just as ink would be absorbed by other writing materials as well. ${ }^{53}$

This imagery of the human body 'drinking letters', situated at the edges of ancient writing, has a rather reflective, almost metaphysical ring to it. ${ }^{54}$ This sensation becomes even stronger in the case of another text, a fragment of the Roman Republican lyric poet Laevius, who wrote:

$$
-\smile-\smile \text { fac papyrin }<a>\text { haec terga habeant stigmata }
$$

make sure that those backs show the whip-marks that pertain to the papyrus

(Laev. carm. frg. 16 B1.)

Here the stationery itself, papyrus, is subject to penal writing, receiving stigmata. The comic playwright Plautus, in turn, had driven this image of writing and punishment even further, suggesting that a whip was designed to inscribe the back of a slave:

\footnotetext{
${ }^{53}$ Note, too, that the text, too, refers to the ancient stonecutter's practice of outlining the letters first before commencing the process of cutting the stone itself (adumbrata inscriptione). A sensible discussion of this passage can now be found in N. W. Slater, Eumolpus Poeta at Work: Rehearsed Spontaneity in the Satyricon, in: E. Minchin (ed.), Orality, Literacy and Performance in the Ancient World. Orality and literacy in the ancient world 9 (Mn. suppl. 335), Leiden - Boston 2012, 245-264, esp. 250-252.

${ }^{54}$ This has been explored in a hagiographical context in Prudentius' Peristephanon 9 (cf. also Per. 3), where the skin of a killed teacher is 'inscribed' by the pens of the perpetrators; further on this e. $\mathrm{g}$. A. Taylor, Books, Bones, and Bodies: Hilduin of Saint-Denis and the Relics of Saint Dionysius, in: S. Conklin Akbari and J. Ross (eds.), The Ends of the Body: Identity and Community in Medieval Culture, Toronto 2013, 25-60, esp. 36.
} 
corpus tuum uirgis ulmeis inscribam

I shall inscribe your body with elm-tree branches

(Plaut. com. frg. 166 Lindsay)

Considering just how Roman handwriting actually looked, the comparison to whipmarks is a - no pun intended - striking one.

\section{Some Conclusions}

There are numerous avenues that still remain to be explored. For example, magical texts are likely to contain references to inscriptions on objects that do not tend to survive. ${ }^{55}$ What about perfectly fathomable modes such as writing notes on one's skin (with charcoal or ink - related to the idea that was alluded to in the Petronius story), painting and drawing on the surfaces of roads for games or quick orientation (or fun)? What about flowerbeds or plantations, carefully laid-out pebble stones, intelligently arranged buildings or even entire settlements? What about stone and brickwork in walls, based on colour variation? What about polychromic glass? None of these options would seem impossible to execute with the means available to the civilisations of the Roman world. ${ }^{56}$

What could be shown, however, was that an investigation of the fringes of the Roman epigraphic habit allows us to advance our understanding of:

- The ubiquity of lettering and texts in the ancient world, potentially to a much higher degree than the texts that are traditionally covered by Roman epigraphists tend to suggest;

- The frame of mind and imagery that lies behind the lettered world of Graeco-Roman antiquity - including literary imaginations of inscriptions that never actually existed (cf. the $\mathrm{H} / \mathrm{hyacinthus} \mathrm{story} \mathrm{in}$ particular);

- The degree of common and widespread literacy (as opposed to an appreciation of literary masterpieces!) that is required to allow for most of the categories mentioned in this paper to develop their full potential.

Yet, the account of 'fringe epigraphy' from Roman sources as presented here can only constitute an initial step of what ultimately must be a rather broader investigation still, also in the context of adjacent and earlier, or subsequent, cultures. It does not aspire to completeness or exhaustiveness in coverage in any way: if anything, it is an invitation to think differently and to introduce evidence to the broader discourse that, in spite of its firm and undisputable nature, is not normally considered. It potentially leaves us with an idea, however, that it may be worth re-thinking the Roman world as a fundamentally lettered one - and a world that was imagined to be lettered by the ancients as well. In that regard, there may be a good case to be made for epigraphy as

\footnotetext{
${ }^{55}$ Further on this see recently R.L. Gordon - F. Marco Simón (edd.), Magical Practice in the Latin West, Leiden 2010 and M. Piranomonte - F. Marco Simón (edd.), Contesti magici-contextos mágicos, Rome 2012.

${ }^{56}$ One could go even further and think of letters traced in the snow, into growing crops, vel sim.
} 
the study of the lettered environment (as opposed to the various forms in which one tends to study lettered stationery). 